Research Article

\section{Effect of ginger flour}

\section{supplementation on fermented}

\section{millet flour 'ibyer' anti-diabetic and biochemical properties}

\author{
Adakole $\mathrm{MI}^{1}$, Ikya $\mathrm{JK}^{1}$, Girgih $\mathrm{AT}^{1}$, Ogori $\mathrm{AF}^{2 *}$ and Upev $\mathrm{V}^{3}$ \\ 'Department of Food Science and Technology, Federal University of Agriculture, Makurdi, \\ Benue State, Nigeria \\ ${ }^{2}$ Department of Home Sciences, Faculty of Agriculture, Federal University, Gashua, P.M.B.1005 \\ Gashua, Yobe State, Nigeria \\ ${ }^{3}$ Department of Veterinary Physiology, College of Vetinary Medicime Federal university of \\ Agriculture Makurdi, Beneu State, Nigeria
}

\section{Abstract}

A mucoso-respiratory highly contagious disease; COVID-19, has led to tremendous global health and economy damages. This virus could be dampened through home use of fermented bio food material. Fermented millet flour (ibyer) is an indigenous non-alcoholic gruel made from cereals either (maize, sorghum and millet). It is prepared by cooking reconstituted cereal flour or wet milled paste with water. In this study, fermented millet $\mathrm{fl}$ our supplemented with ginger powder blends were formulated in the ratio 100:0, 95:5, 90:10, 85:15, 80:20, 75:25 and 70:30 for the production of gruel. The blends were subjected to feeding trial experiment using wistar albino rat. Results analysis revealed that Serum cholesterol was less than $200 \mathrm{mg} / \mathrm{dl}$. The fasting blood glucose was also within the recommended range $(67.7-125.0 \mathrm{mg} / \mathrm{dl})$. The biochemical parameters were within recommended range, total serum protein ranged from 5.82-7.06 g/L, Alanine aminotransferase ranged from 28.53 to $41.13 \mathrm{iu} / \mathrm{L}$, Aspartate aminotransferase ranged from 28.50 to $48.66 \mathrm{iu} / \mathrm{L}$. The albino rats showed slight increase in body weight throughout the experimental period, ranging from $78.67-103.80 \mathrm{~g}$. The experiment shows that the diet did not have any adverse effect on the experimental animals and were within the recommended range hence a good anti diabetic blend and has excellent biochemical profile properties for homes use.

\section{More Information}

*Address for Correspondence: Ogori AF, Department of Home Sciences, Faculty of Agriculture, Federal University, Gashua, P.M.B.1005 Gashua, Yobe State, Nigeria, Email: ogorifaradayadanu@gmail.com; ogorifaraday@gmail.com

Submitted: December 14, 2020

Approved: December 28, 2020 Published: December 29. 2020

How to cite this article: Adakole MI, Ikya JK, Girgih AT, Ogori AF, Upev V. Effect of ginger flour supplementation on fermented millet flour 'ibyer' anti-diabetic and biochemical properties. Arch Food Nutr Sci. 2020; 4: 029-035.

DOI: 10.29328/journal.afns.1001025 ORCiD: orcid.org/0000-0001-8820-5868

Copyright: @ 2020 Adakole MI, et al. This is an open access article distributed under the Creative Commons Attribution License, which permits unrestricted use, distribution, and reproduction in any medium, provided the original work is properly cited.

Keywords: Diabetics; Biochemical; Fermented; Millet; Ginger; Flour; Supplementation

Check for updates

OPEN ACCESS

\section{Introduction}

Diabetes mellitus is a serious health hazard currently affecting more than 220 million people worldwide and is expected to afflict 400 million by 2030 [1]. It is a common health problem and a serious metabolic disorder associated with many functional and structural complications [2]. Clinical definitions of disease often obscure different mechanistic subtypes. It is a chronic lifelong condition that affects the body's ability to use the energy found in food. It is caused by the body not producing enough insulin or not being able to utilize it for the absorption of glucose to provide the needed energy or may be a combination of both conditions [3]. It is a clinical syndrome characterized by hyperglycemia due to absolute or relative deficiency of insulin and/or insulin sensitivity [4].
Chronic hyperglycemia leads to long term damage, dysfunction and eventually the failure of organs, especially the eyes, kidneys, nerves and cardiovascular system [4,5]. When diabetes is left untreated it could result into heart disease, stroke, blindness and nerve damage to the legs. According to World Health Organization, the diabetes population is likely to increase to 300 million or more by the year 2025. Currently available therapies for diabetes include insulin and various oral antidiabetic agents such as sulfonylureas, metformin, meglitinides, biguanides, glinides and recently stem cell implants, which are used as monotherapy or in combination to achieve better glycemic regulation. Many of these oral antidiabetic agents have a number of serious adverse effects. Thus, the management of diabetics without any side effects is still a challenge [6]. 
Millets are known to have a low glycemic index as suggested by some in vivo studies however all of these studies have mainly focused on millet products from composite flour $[7,8]$. Starch digestibility studies on the $100 \%$ cooked millet flour have been rarely done. Dietary fibre, phenolics and lipids which are mainly lost during decortication may also affect in vitro starch digestibility $[9,10]$. Removal of protein and lipid or both has shown to significantly increase the expected glycemic index (eGI) [11].

Ginger has been used for thousands of years for the treatment of numerous ailments, such as colds, nausea, arthritis, migraines, and hypertension. The medicinal, chemical, and pharmacological properties of ginger have been extensively reviewed [12], as preventive or therapeutic agents [13].

There are no studies to compare the in vitro starch digestibility of cooked millet flour from whole and decorticated grains hence the study limitations. Due to difference in the grain morphology between millets and other cereals, the efforts to decorticate millet by known cereal milling methodologies including abrasion, friction mills or other dehulling techniques without biofunctioal losses have not been successful. The present study was aimed at assessing the quality of fermented millet (Pennisetum glacum) flour supplemented with ginger (Zingiber officinalis) powder its anti-diabetic properties and serum biochemistry profiles using albino rats.

\section{Materials and methodology}

\section{Sample preparation}

The most common flour production is to convert the grain/ tubers in the form of flour which is achieved by milling, using hammer mills.

\section{Preparation of fermented millet flour}

The method described by Sengev et al. [14] was used with slight modifications for the production of millet flour. Pearl millet flour was prepared as shown in figure 1. The grains were sorted and cleaned to remove unwanted materials like stones, pebbles and other foreign seeds, before washing with tap water and steeping $(72 \mathrm{~h})$. Therefore, the grains were drained, dried, milled and sieved to get whole pearl millet flour.

\section{Preparation of ginger powder}

Ginger flour will be prepared according to the method of Sekwati-Monang, [15] with slight modification as shown in figure 2 . Fresh ginger roots were sorted by soaking in water to get rid of dirts and to remove unwanted materials, before washing with tap water. The cleaned roots were drained, sliced, sundried, milled using hammer mill and sieved through $600 \mu \mathrm{m}$ aperture size.

\section{Preparation of "ibyer" from fermented millet flour and ginger powder blends}

Ibyer was produced as described by Kure and Wyasu [16] with slight modification. Each sample weighing 100:0, 95:5, 90:10, 85:15, 80:20, 75:25, 70:30 (Table 1) of both fermented millet flour and ginger powder were mixed each with $10 \mathrm{ml}$ of distilled water to form a slurry. It was allowed to ferment for $12 \mathrm{~h} .200 \mathrm{ml}$ of boiling water was added to the slurry which was heated for 10 minutes with continuous stirring to avoid the formation of lumps. The gruel was allowed to cool to $40^{\circ} \mathrm{C}$. The production flow chart is as shown in figure 3.

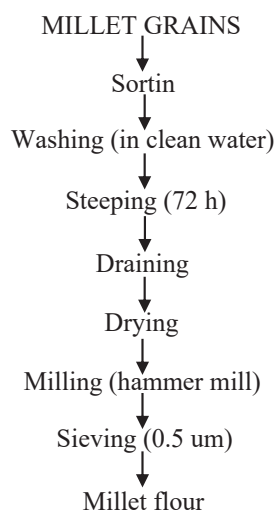

Figure 1: Flow chart for the production of millet flour. Source: Sengev, et al. [14]

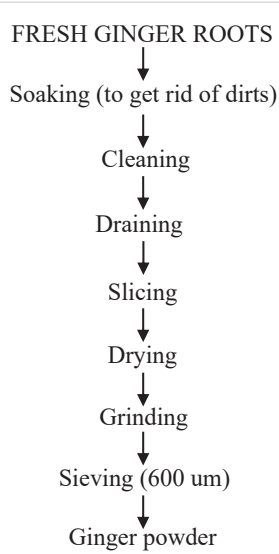

Figure 2: Flow chart for the production of ginger powder. Source: Sekwati-Monang. [11].

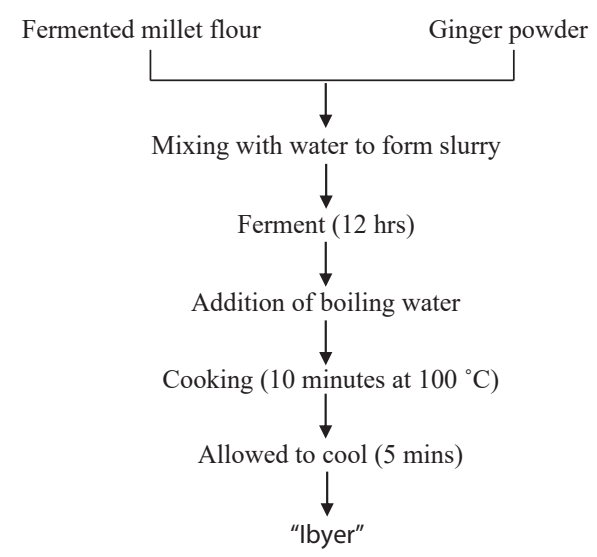

Figure 3: Flow chart for the production of "ibyer". Source: Kure and Wyasu, [16]. 
Table 1: Blend Formulation (\%) of fermented millet flour supplemented with gingerpowder for "ibyer" production.

\begin{tabular}{|c|c|c|}
\hline Sample code & Millet & Ginger \\
\hline 716 & 100 & - \\
\hline 924 & 95 & 5 \\
\hline 839 & 90 & 10 \\
\hline 746 & 85 & 15 \\
\hline 958 & 80 & 20 \\
469 & 75 & 25 \\
\hline 577 & 70 & 30 \\
\hline
\end{tabular}

KEY: $716=M_{100}\left(\right.$ Control), $924=M_{95} G_{5} 839=M_{90} G_{10}, 746=M_{85} G_{15}, 958=M_{80} G_{20}$ $469=M_{75} G_{25}, 577=M_{70} G_{30}$. Where, $M=$ Millet, $G=$ Ginger

\section{Experimental animals' model and their maintenance}

Twenty-one (21) healthy wistar albino rats aged 3 weeks (21 days), weighing $100 \mathrm{~g}$ to $130 \mathrm{~g}$ were obtained from Benue state university, college of health science. Three rats were kept in animal cages in an animal house Department of Home Science and Management, Federal University of Agriculture, Makurdi. The rats were allowed to acclimatize with the laboratory condition for 7 days in well ventilated cages. They were divided into 7 groups of 3 rats each. Each of the rats was given an identification mark in form of an indelible mark on tail, head and back. During the acclimatization period, the rats were allowed access to food and water ad libitum.

\section{Induction of experimental diabetes}

A total of 21 rats (surviving from the normal feeding trial) were used in the experiment. Diabetes was induced by a single intraperitoneal injection at $130 \mathrm{mg} / \mathrm{kg}$ body weight with alloxan monohydrate after the animals were fasted for 24 hours. Blood was collected from the tail vein of the rats after 72 hours of alloxan injection by measuring the initial glucose level using glucometer.

\section{Fasting blood glucose determination}

Rats having fasting blood glucose (FBG) level greater than $200 \mathrm{mg} / \mathrm{dl}$ were confirmed diabetic. The fasting blood glucose was determined at day 17, 24 and 31 respectively for 2 weeks using one touch digital glucometer.

\section{Measurement of body weight}

The body weight of each animal was assessed using an electronic weighing scale once before commencement of the feeding and then every 7 day interval for 28 days.

Blend formulation (\%) of fermented millet flour supplemented with ginger powder for experimental feeding

Diets were prepared using vitalyte (5\%), sucrose $(10 \%)$, corn starch (70\%), rice husk (5\%) and fermented millet flour and gingerpowder (in different proportion) as shown in the Table 2.

\section{Treatment of the animals}

Each group was provided with $100 \mathrm{~g}$ of the respective diet

\begin{tabular}{|c|c|c|c|c|c|c|c|}
\hline \multicolumn{7}{|l|}{ Table 2: Blend formulation for experimental feeding. } \\
\hline Sample code & $\mathbf{7 1 6}$ & $\mathbf{9 2 4}$ & $\mathbf{8 3 9}$ & $\mathbf{7 4 6}$ & $\mathbf{9 5 8}$ & $\mathbf{4 6 9}$ & $\mathbf{5 7 7}$ \\
\hline Millet & 10 & 9.5 & 9 & 8.5 & 8 & 7.5 & 7 \\
\hline Ginger & - & 0.5 & 1 & 1.5 & 2 & 2.5 & 3 \\
\hline Corn starch & 70 & 70 & 70 & 70 & 70 & 70 & 70 \\
\hline Vitalyte & 5 & 5 & 5 & 5 & 5 & 5 & 5 \\
\hline Rice husk & 5 & 5 & 5 & 5 & 5 & 5 & 5 \\
\hline Sucrose & 10 & 10 & 10 & 10 & 10 & 10 & 10 \\
\hline Total & 100 & 100 & 100 & 100 & 100 & 100 & 100 \\
\hline
\end{tabular}

KEY: $716=M_{100}$ (Control), $924=M_{95} G_{5}, 839=M_{90} G_{10}, 746=M_{85} G_{15}, 958=M_{80} G_{20}$, $469=M_{75} G_{25}, 577=M_{70} G_{30}$. Where, $M=$ Millet, $G=$ Ginger

on daily basis for 28 days and the left over was collected each next morning and weighed. The animals were also provided with clean tap water ad libitum throughout the experimental period. The rats were weighed before and after acclimatization and on weekly basis throughout the experimental feeding period. The mean weekly weight gain was computed.

\section{Serum total protein determination}

The quantitative determination of total protein concentration in serum was measured by biuret method using Randox Diagnostic Assay kits.

Principle: Protein react with cupric ions in alkaline solution to form a colored chelate. The absorbance of final colour is proportional to the concentration of total protein in the serum sample at $546 \mathrm{~nm}$.

Protein $+\mathrm{Cu}++$ Alkaline $\mathrm{pH} \rightarrow \mathrm{Cu}$ - protein complex

Procedure: The reagent $(1.0 \mathrm{ml})$ of reagent was pipetted into three different clean dry tubes as blank, standard and test sample. After that, $20 \mathrm{uL}$ of protein standard and $20 \mu \mathrm{L}$ of serum sample were added in respective tube then mixed properly. The mixture was incubated at $37{ }^{\circ} \mathrm{C}$ for 5 minutes and absorbance was measured at $546 \mathrm{~nm}$ against the reagent blank in a spectrophotometer and calculated as follows.

Total protein concentration $(\mathrm{mg} / \mathrm{dL})=\frac{\text { Absorbance of test }}{\text { Absorbance of standard }} \times 6.27$ Nitrogen

\section{Total cholesterol determination}

Quantitative determination of total cholesterol in blood was measured by CHOD/PAP methods using TECO Diagnostic kit USA.

Assay principle: For total cholesterol, esters were hydrolyzed by cholesterol esterase to give free cholesterol and fatty acids. In subsequent reaction, cholesterol oxidase oxidizes the 3-OH group of free cholesterol to liberate cholest-4-en-3one and hydrogen peroxidase. In the presence of peroxidase, hydrogen peroxidase couples with 4-aminoanlipyrine (4-AAP) and phenol to produce red quinoneimine dye. Absorbance colored dye is measured at $505 \mathrm{~nm}$ and is proportional to amount of total cholesterol concentration in serum sample.

Procedure: The reagent $(1.0 \mathrm{ml})$ of reagent was pipetted 
into three clean dry tubes labelled as blank, standard and test. After that, $10 \mathrm{uL}$ of cholesterol standard and $10 \mathrm{uL}$ of serum sample was added in respective tubes labelled with standard test. The mixture was incubated at $37^{\circ} \mathrm{C}$ for 10 minutes. The absorbance of the test sample as well as standard was measured immediately against their respective blank at 505 $\mathrm{nm}$ in a UV-Visible spectrophotometer and the results were calculated using the formula given below.

Total Cholesterol $(\mathrm{mg} / \mathrm{dL})=\frac{\text { Absorbance of test sample } \times 200 \text { cholesterol standard }}{\text { Absorbance of standard }}$

\section{Serum as partate aminotransferase (AST) determinations}

The serum AST was estimated colorimetrically by the 2,4-dinitrophenylhydrazine (2,4-DNPH) method using Randox Diagonistic Kit (Randox Laboratories Ltd, Crumlin, UK).

Principle: The enzyme aspartate aminotransferase (glutamate oxaloacetate transaminase-GOT) catalyzes an exchange of amino acid group of aspartate for an $\alpha$-ketoglutarate (i.e. coverts L-aspartate and $\alpha$-ketoglutarate to oxaloacetate and L- glutamate). The oxaloacetate formed react with 2,4 , dinitrophenyl hydrazine to produce a hydrazine derivative, which in an alkaline medium (sodium hydroxide) produces a brown coloured complex whose intensity can be read by a spectrophotometer.

L-aspartate $+\alpha$-ketoglutarate AST $\rightarrow$ 0xaloacetate $\rightarrow+$ L-glutamateOxaloacetate $+2,4$, DNPH NaOH 2,4, Dinitrophenyl hydrazone (Brown colored complex)

Procedure: Two (2) test tubes labelled "blank" and "sample" were prepared. Procedure 1(measurement against a reagent blank) was adopted for the determination of serum AST. The solution (0.5 ml) R1 (L-aspartate, buffer, $\alpha$-ketoglutarate) was placed in the two test tubes each. Thereafter, $0.1 \mathrm{ml}$ of serum (representing 21 samples of the 7 groups) was placed in the marked "sample". Also $0.1 \mathrm{ml}$ of distilled water was added to the "blank" test tube. The content of the tubes were mixed thoroughly and incubated in a water bath at $37{ }^{\circ} \mathrm{C}$ for 30 minutes. After 30 minutes of incubation, $0.5 \mathrm{ml}$ solution of $\mathrm{R} 2(2,4, \mathrm{DNPH})$ was added to both test tubes mixed and allowed to stand for 20 minutes at room temperature. The absorbance of the content was measured at $540 \mathrm{~nm}$ using spectrophotometer.

\section{Serum alanine aminotransferase (ALT) determination}

The serum ALT was estimated colorimetrically by the 2.4- dinitrophenylhydrazine (DNPH) method using Randox Diagnostic Kit (Randox Laboratories Ltd., Crumlin, UK).

Principle: The enzyme alanine aminotransferase (glutamate pyruvate transaminase- GPT) catalyzes an exchange of amino acid group of alanine for an $\alpha$-keto group of $\alpha$-ketoglutarate (i.e. converts L-alanine and $\alpha$-ketoglutarate to pyruvate and L- glutamate). The pyruvate formed react with 2,4-dinitrophenylhydrazine (2,4- DNPH) to produce a hydrazine derivative, which in an alkaline medium (sodium hydroxide) produces a brown coloured complex whose intensity can be read by a spectrophotometer

L-alanine $+\alpha$-ketoglutarate ALT $\rightarrow$ pyruvate + L-glutamat

Pyruvate $+2,4$, DNPH NaOH $\rightarrow$ 2,4, dinitrophenyl hydrazone (Brown colored complex)

Procedure: Two (2) test tubes labeled "blank" and "sample" were prepared. Procedure 1(measurement against a reagent blank) was adopted for the determination of serum ALT. The solution $(0.5 \mathrm{ml})$ of solution R1 (phosphate buffer, L-alanine and $\alpha$-ketoglutarate) was placed in the two test tubes each. Thereafter, $0.1 \mathrm{ml}$ of serum (representing 21 samples of the 7 groups) was placed in the marked "sample". Also $0.1 \mathrm{ml}$ of distilled water was added to the "blank" test tube. The content of the tubes were mixed thoroughly and incubated in a water bath at $37{ }^{\circ} \mathrm{C}$ for 30 minutes. After 30 minutes of incubation, $0.5 \mathrm{ml}$ solution of R2 (2,4, DNPH) was added to both test tubes, mixed and allowed to stand for 20 minutes at room temperature and the content was measured at $540 \mathrm{~nm}$ using spectrophotometer.

\section{Statistical analysis}

The mean and standard deviation of the result data from the experiment was calculated and analyzed using single factor analysis of variance (ANOVA) in the statistical package for social science (SPSS, 2003) Software (SPSS version 12. 0.1 for windows). The Duncan's New Multiple Range Test was used to determine the significance difference between mean values.

\section{Result}

Fasting blood sugar level $(\mathrm{mg} / \mathrm{dL})$ of the experimental alloxan induced albino rats fed fermented millet flour supplemented with ginger powder is seen on table 3 . The experimental albino rats were considered diabetic when the glucose level got above $200 \mathrm{mg} / \mathrm{dL}$. The Table 3 shows that the fasting blood glucose of the experimental animals increased significantly on day 17 which shows the albino rats were hyperglycemic after alloxan induction in all the groups. There was a slight decrease in glucose level of the experimental albino rats on day 24 and day 31 in all the groups apart from the control group (716) which was unstable due to $0 \%$ ginger.

Serum cholesterol level (mg/dL) of experimental albino rats fed fermented millet flour supplemented with ginger powder is shown on table 4 . The serum cholesterol level of experimental albino rats fed fermented millet flour spiced with ginger powder. The serum cholesterol level decreased from day 7 to day 14 while an increase on day 21 due to the effect of the alloxan monohydrate and a decrease on day 28. The control group was unstable due to the absence of ginger in the diet. The values were within the recommended range for cholesterol level $(<200 \mathrm{mg} / \mathrm{dL})$. 
Table 3: Fasting blood glucose level ( $\mathrm{mg} / \mathrm{dL}$ ) of the experimental alloxan monohydrate induced albino rats fed fermented millet flour supplemented with ginger powder.

\begin{tabular}{|c|c|c|c|c|}
\hline \multirow{2}{*}{ Sample code } & \multicolumn{2}{|c|}{ Initial (FBG) } & \multicolumn{2}{|c|}{ Fasting Blood Glucose (FBG) mg/dL } \\
\hline & Day 14 & Day 17 & Day 24 & Day 31 \\
\hline 716 & $78.0 \pm 0.57^{a}$ & $128.7 \pm 21.1^{a}$ & $168.0 \pm 45.5^{\mathrm{a}}$ & $190.0 \pm 54.8^{a}$ \\
\hline 924 & $78.3 \pm 6.33^{a}$ & $151.0 \pm 14.4^{a}$ & $148.7 \pm 7.7^{\mathrm{a}}$ & $125.0 \pm 8.08^{a}$ \\
\hline 839 & $101.0 \pm 8.00^{b}$ & $374.4 \pm 112.0^{b}$ & $256.3 \pm 18.6^{a}$ & $219.0 \pm 106.6^{\mathrm{a}}$ \\
\hline 746 & $111.0 \pm 3.46^{b}$ & $183.3 \pm 37.7^{\mathrm{a}}$ & $161.0 \pm 63.12^{\mathrm{a}}$ & $157.0 \pm 73.3^{\mathrm{a}}$ \\
\hline 958 & $67.7 \pm 11.5^{\mathrm{a}}$ & $214.7 \pm 49.3^{\mathrm{ab}}$ & $208.0 \pm 68.7^{\mathrm{a}}$ & $167.6 \pm 37.9^{a}$ \\
\hline 469 & $76.7 \pm 3.75^{\mathrm{a}}$ & $158.3 \pm 4.17^{\mathrm{a}}$ & $147.0 \pm 21.50^{\mathrm{a}}$ & $142.0 \pm 16.7^{\mathrm{a}}$ \\
\hline 577 & $76.7 \pm 1.45^{\mathrm{a}}$ & $204.7 \pm 10.7^{\mathrm{a}}$ & $142.7 \pm 36.7^{\mathrm{a}}$ & $132.3 \pm 31.3^{a}$ \\
\hline
\end{tabular}

Values are mean \pm SD of 3 replicate determinant, $n=3$; values bearing different superscripts $(a, b, c)$ in the same row are significantly $(p<0.05)$ different.

KEY: $716=M_{100}$ (Control), $924=M_{95} G_{5} 839=M_{90} G_{10}, 746=M_{85} G_{15}, 958=M_{80} G_{20}, 469=M_{75} G_{25}, 577=M_{70} G_{30}$. Where, $M=M i l l e t, G=G i n g e r$

Table 4: Serum cholesterol level $(\mathrm{mg} / \mathrm{dL})$ of experimental albino rats fed with fermented millet flour supplemented with ginger powder.

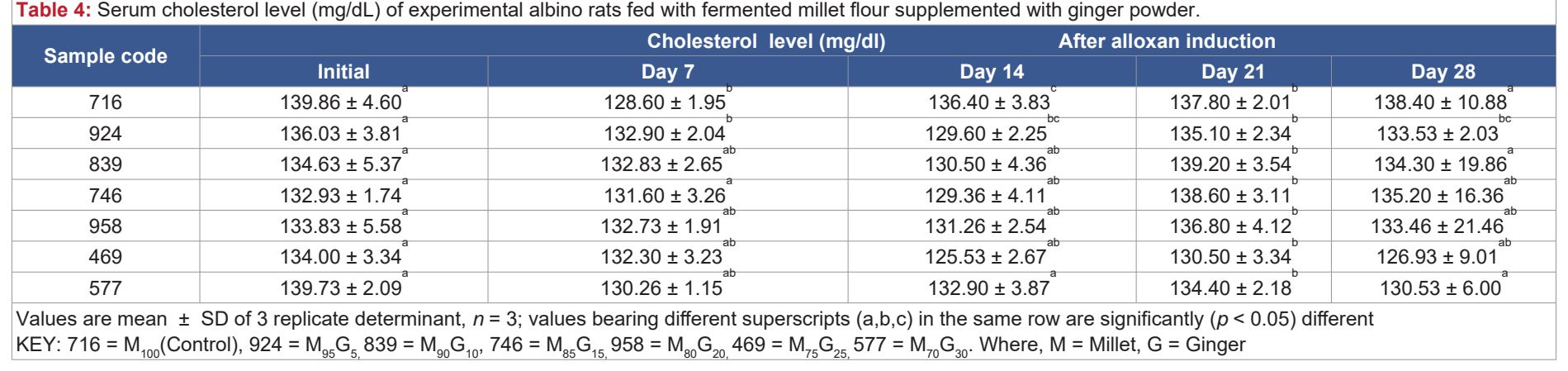

Serum total protein content $(\mathrm{g} / \mathrm{L})$ of the experimentalalbino rats fed fermented millet flour supplemented with ginger powder is shown on table 5 . The serum total protein of the albino rats fed fermented millet flour supplemented with ginger powder. The serum total protein increased from day 7 to day 14 in all the groups while a decrease in day 21 when alloxan was introduced because alloxan caused a defect in the secretion of protein. On day 28 the serum total protein increased while the control group was unstable from the initial day to day 28 due to the absence of ginger. The values obtained were within the recommended range $3.5-8 \mathrm{~g} / \mathrm{L}$.

Aspartate aminotransferase (iu/L) of experimental albino rats fed fermented millet flour supplemented with ginger powder is shown on table 6 . The AST value of the experimental albino rats fed fermented millet flour supplemented with ginger powder reveals an enzyme found in the muscle tissue and other organs such as pancreas, kidney, heart cells and liver. The AST value was within the recommended range reported by Al-Amin, et al. [17]. The AST decreased from day 7 to day 14 and increased on day 21 due to the effect of alloxan. On day 28 the AST reduced which indicate that the animals were utilizing their diet well. The values were within the recommended range $(10-55 \mathrm{iu} / \mathrm{L})$.

Alanine aminotransferase (iu/L) of experimental animals fed fermented millet flour supplemented with ginger powder is shown on table 7. The ALT is a liver test. It is a test used to detect whether a liver is functioning.

The Table 7 shows the ALT value of the experimental albino rats fed fermented millet flour supplemented with ginger powder. The ALT decreased from day 7 to day 14 during the normal feeding trial and increased on day 21 due to the effect of alloxan monohydrate. There was an increase on day 28 in all the groups apart from the control group which was unstable from the initial to the day 28 . The values obtained were within recommended range (7-56 iu/L).

\section{Discussion}

Fasting Blood Glucose level of experimental alloxan monohydrate induced albino rats fed fermented millet flour supplemented with ginger powder is shown in table one. From the table 1, the FBG of the experimental albino rats showed that at day 14 when the alloxan monohydrate was introduced, the FBG was checked after $72 \mathrm{H}$ of induction and the values were high showing that the animals were diabetic. At day 24 the glucose level reduced indicating that the diet was able to bring down the glucose level. The feeding continued to day 31 and when the glucose level was checked it reduced more than the day 24 and this is due to the presence of Zingiberene and ethanolic extract found in ginger thereby lowering the blood glucose level by inhibition of oxidative stress and antiinflammatory process, thereby increasing insulin sensitivity. The control sample was unstable due to the absence of ginger. This result agrees with the report of Shanmugam, et al. [18] that worked on Neuroprotective effect of ginger on antioxidant enzymes in streptozotocin - induced diabetic rats.

Cholesterol is a waxy, fat like substance that is found in all the cells in the body. Cholesterol is a naturally occurring fat that the body needs to produce important structure and chemicals.

From table 4, the cholesterol level decreased from day 7 to day 14. After alloxan induction at day 21, the cholesterol level increased due to the effect of alloxan. At day 28 the cholesterol level reduced due to the effect of ginger and millet 
Table 5: Total serum protein content $(\mathrm{g} / \mathrm{L})$ of the experimental albino rats fed fermented millet flour supplemented with ginger powder.

\begin{tabular}{|c|c|c|c|c|c|}
\hline \multirow{2}{*}{ Sample code } & \multicolumn{3}{|c|}{ Total serum protein } & \multicolumn{2}{|c|}{ After alloxan induction } \\
\hline & Initial & Day 7 & Day 14 & Day 21 & Day 28 \\
\hline 716 & $6.63 \pm 0.17$ & $7.06 \pm 0.18$ & $7.36 \pm 0.26$ & $5.90 \pm 0.21$ & $6.06 \pm 0.08$ \\
\hline 924 & $6.60 \pm 0.20^{a}$ & $6.65 \pm 0.06^{c}$ & $6.76 \pm 0.29$ & $5.80 \pm 0.12^{a}$ & $6.00 \pm 0.36^{\mathrm{a}}$ \\
\hline 839 & $6.30 \pm 0.23^{a}$ & $6.31 \pm 0.38^{a b}$ & $6.33 \pm 0.26^{a b}$ & $5.70 \pm 0.22^{a}$ & $6.00 \pm 0.20^{\circ}$ \\
\hline 746 & $6.26 \pm 0.32^{a}$ & $6.28 \pm 0.37^{a}$ & $6.36 \pm 0.14^{a b}$ & $6.30 \pm 0.28^{a}$ & $6.70 \pm 0.26^{8}$ \\
\hline 958 & $6.36 \pm 0.41^{a}$ & $6.39 \pm 0.46^{a b}$ & $6.42 \pm 0.20^{a b}$ & $5.72 \pm 0.29^{a}$ & $5.86 \pm 0.23^{\mathrm{a}}$ \\
\hline 469 & $6.53 \pm 0.44^{a}$ & $6.54 \pm 0.37^{a b}$ & $6.63 \pm 0.38^{a b}$ & $5.82 \pm 0.40^{\mathrm{a}}$ & $5.86 \pm 0.24$ \\
\hline 577 & $6.30 \pm 0.16^{a}$ & $6.39 \pm 0.18^{a b}$ & $6.42 \pm 0.29^{a}$ & $5.91 \pm 0.21^{\mathrm{c}}$ & $6.10 \pm 0.23^{8}$ \\
\hline
\end{tabular}

Values are mean $\pm \mathrm{SD}$ of 3 replicate determinant, $n=3$; values bearing different superscripts $(\mathrm{a}, \mathrm{b}, \mathrm{c})$ in the same row are significantly $(p<0.05)$ different KEY: $716=M_{100}$ (Control), $924=M_{95} G_{5} 839=M_{90} G_{10}, 746=M_{85} G_{15}, 958=M_{80} G_{20}, 469=M_{75} G_{25}, 577=M_{70} G_{30}$. Where, $M=M i l l e t, G=G i n g e r$

Table 6: Aspartate aminotransferase (iu/l) of the experimental albino rats fed fermented millet flour supplemented with ginger powder.

\begin{tabular}{|c|c|c|c|c|c|}
\hline \multirow{2}{*}{ Sample code } & \multicolumn{3}{|c|}{ Aspartate aminotransferase (AST) } & \multicolumn{2}{|c|}{ After alloxan induction } \\
\hline & Initial & Day 7 & Day 14 & Day 21 & Day 28 \\
\hline 716 & $42.86 \pm 2.83^{\mathrm{d}}$ & $32.93 \pm 6.01$ & $35.36 \pm 2.78^{\mathrm{d}}$ & $37.60 \pm 3.74$ & $48.66 \pm 7.44$ \\
\hline 924 & $36.83 \pm 8.31^{a}$ & $29.30 \pm 2.05^{a}$ & $28.50 \pm 1.15^{a}$ & $39.80 \pm 2.20^{b}$ & $28.43 \pm 4.86^{a}$ \\
\hline 839 & $34.50 \pm 3.23^{a}$ & $33.30 \pm 3.31^{\mathrm{a}}$ & $32.63 \pm 2.61^{a}$ & $34.60 \pm 3.41^{b}$ & $33.43 \pm 10.38$ \\
\hline 746 & $35.70 \pm 4.05^{a}$ & $33.53 \pm 3.10^{a}$ & $32.63 \pm 1.65^{a}$ & $33.90 \pm 2.10^{b}$ & $32.53 \pm 3.57^{\circ}$ \\
\hline 958 & $39.50 \pm 2.54^{a}$ & $37.20 \pm 2.38^{a}$ & $36.13 \pm 4.78^{a}$ & $38.50 \pm 3.42^{b}$ & $36.43 \pm 9.72^{a}$ \\
\hline 469 & $46.80 \pm 6.90^{\mathrm{a}}$ & $43.60 \pm 2.52^{a}$ & $38.46 \pm 6.83^{a}$ & $39.60 \pm 6.92^{b}$ & $38.16 \pm 1.53^{\mathrm{a}}$ \\
\hline 577 & $40.16 \pm 1.72^{a}$ & $35.60 \pm 2.52^{a}$ & $34.16 \pm 4.31^{a}$ & $34.20 \pm 3.72^{b}$ & $33.66 \pm 7.58^{a}$ \\
\hline
\end{tabular}

Values are mean $\pm \mathrm{SD}$ of 3 replicate determinant, $n=3$; values bearing different superscripts (a,b,c) in the same row are significantly $(p<0.05)$ different

KEY: $716=M_{100}\left(\right.$ Control), $924=M_{95} G_{5}, 839=M_{90} G_{10}, 746=M_{85} G_{15}, 958=M_{80} G_{20}, 469=M_{75} G_{25}, 577=M_{70} G_{30}$. Where, $M=$ Millet, $G=G i n g e r$

Table 7: Alanine aminotransferase (iu/L) of experimental albino rats fed fermented millet flour supplemented with ginger powder

\begin{tabular}{|c|c|c|c|c|c|}
\hline \multirow{2}{*}{ Sample code } & \multicolumn{3}{|c|}{ Alanine aminotransferase (ALT) } & \multicolumn{2}{|c|}{ fter alloxan induction } \\
\hline & Initial & Day 7 & Day 14 & Day 21 & Day 28 \\
\hline 716 & $37.56 \pm 2.97^{a}$ & $32.36 \pm 3.45^{\mathrm{a}}$ & $33.50 \pm 0.54^{a}$ & $33.90 \pm 2.10^{\circ}$ & $34.33 \pm 24.26$ \\
\hline 924 & $37.60 \pm 4.07^{a}$ & $30.96 \pm 3.97^{a}$ & $29.83 \pm 5.11^{a}$ & $33.31 \pm 3.11^{b}$ & $29.96 \pm 3.18^{a}$ \\
\hline 839 & $38.00 \pm 3.02^{a}$ & $34.63 \pm 3.11^{\mathrm{a}}$ & $31.66 \pm 4.91^{\mathrm{a}}$ & $37.40 \pm 4.98^{b}$ & $36.06 \pm 13.32$ \\
\hline 746 & $39.90 \pm 2.01^{a}$ & $39.10 \pm 5.21^{\mathrm{a}}$ & $33.13 \pm 2.54^{\mathrm{a}}$ & $34.80 \pm 3.12^{b}$ & $41.13 \pm 9.89^{a}$ \\
\hline 958 & $36.33 \pm 1.64^{a}$ & $36.02 \pm 5.21^{a}$ & $34.56 \pm 3.04^{a}$ & $35.30 \pm 3.98^{b}$ & $33.63 \pm 10.10^{a}$ \\
\hline 469 & $39.83 \pm 2.52^{a}$ & $38.16 \pm 5.49^{a}$ & $28.53 \pm 1.68^{a}$ & $30.20 \pm 4.38^{b}$ & $29.24 \pm 3.84^{a}$ \\
\hline 577 & $34.60 \pm 3.81^{a}$ & $31.10 \pm 5.21^{a}$ & $29.24 \pm 3.04^{a}$ & $35.82 \pm 3.94^{b}$ & $34.20 \pm 8.42^{a}$ \\
\hline
\end{tabular}

Values are mean $\pm \mathrm{SD}$ of 3 replicate determinant, $n=3$; values bearing different superscripts $(\mathrm{a}, \mathrm{b}, \mathrm{c})$ in the same row are significantly $(p<0.05)$ different

KEY: $716=M_{100}$ (Control), $924=M_{95} G_{5}, 839=M_{90} G_{10}, 746=M_{85} G_{15}, 958=M_{80} G_{20}, 469=M_{75} G_{25}, 577=M_{70} G_{30}$. Where, $M=M i l l e t, G=G i n g e r$

and the experimental animals were utilizing their diet well. The cholesterol level increased from day 7 to day 28 due to the absence of ginger.

The Serum total protein is a biochemical test for measuring the total amount of protein in serum. Protein in serum is made up of albumin and globulin. From Table 5, the serum total protein increased from day 7 to day 14 during the normal feeding trial.

After alloxan was induced at day 21 the serum total protein decreased due to the effect of the alloxan. At day 28, the serum total protein increased which means the animals were utilizing their diet well. The control was unstable from day 7 to day 28 because the diet does not contain ginger.

AST are enzymes found mainly in the muscle tissues and other organs such as pancreas, kidney, heart cells and liver. From Table 6, the AST reduced from day 7 to day 14. After alloxan induction at day 21, the AST increased because of increased conditions of cell damage and also due to the effect of alloxan. At day 28, the AST reduced showing that ginger powder at various concentration did not have any damage to the heart, muscle, brain and kidney that are vital organs in the body because the values were within range reported by Al-Amin, et al. [17] that worked on Antidiabetic and hypolipidaemic properties of ginger (Zingiber officinale) in streptozotocin induced diabetic rats. The control sample was unstable from day 7 to day 28 of the feeding trial.

Alanine aminotransferase ALT is a liver test. It is known as the main liver marker. It is an enzyme found in the cells of the liver. From Table 7, the ALT reduced from day 7 to day 14 and the reduction shows that ginger powder at various concentrations did not have any damage to the liver, heart, muscle, brain and kidney that are vital organs in the body because the values were within range reported by Al-Amin, et al. [16] that worked on Antidiabetic and hypolipidaemic properties of ginger (Zingiber officinale) in streptozotocin induced diabetic rats. After alloxan induction, the ALT increased at day 21 and reduced at day 28. The control experienced increment from day 7 to day 28 due to the absence of ginger.

\section{Conclusion}

Fermented millet flour spiced with ginger flour has favourable impact on measurements of glucose in rats with 
diabetes. Ginger has effects on carbohydrate metabolism and insulin sensitivity. Ginger was significantly effective in lowering serum glucose, serum cholesterol in the diabetic rats compared with the control. The biochemical parameters showed that cholesterol level, AST, ALT decreased. There was a fluctuation in the control sample however, during alloxan induction, there was a slight decrease in cholesterol level, AST and ALT from day 21 to day 28 while the total serum protein increased from day 21 to day 28.

\section{Acknowledgement}

The authors acknowledged the department of Food science and Technology for support in the course of this research.

\section{References}

1. Wild S, Roglic G, Green A, Sicree R, King H. Global prevalence of diabetes: estimates for the year 2000 and projections for 2030. Diabetes care. 2004; 27: 1047-1053

PubMed: https://pubmed.ncbi.nlm.nih.gov/15111519/

2. Meyer K, Deutscher J, Anil M, Berthold A, Bartsch KW. Serum androgen levels in adolescents with type I diabetes: relationship to pubertal stage and metabolic control. J Endocrinol Invest. 2000; 23: 362-368. PubMed: https://pubmed.ncbi.nlm.nih.gov/10908163/

3. Ojewole JAO. Analgesic, antiinflammatory and hypoglycaemic effects of ethanol extract of Zingiber officinale (Roscoe) rhizomes (Zingiberaceae) in mice and rats. Phytother Res. 2006; 20: 764-772. PubMed: https://pubmed.ncbi.nlm.nih.gov/16807883/

4. Jafri SA, Abass S, Qasim M. Hypoglycemic effect of ginger (Zingiber officinale) in alloxan induced diabetic rats (Rattus norvagicus). Pak Vet J. 2011; 31: 160-162.

5. American Diabetes Association. Nutrition Recommendations and interventions for diabetes. 2009.

6. Hamden K, Carreau S, Jamoussi K, Miladi S, Lajmi S, et al. 1Alpha, 25 dihydroxyvitamin D3: therapeutic and preventive effects against oxidative stress, hepatic, pancreatic and renal injury in alloxan-induced diabetes in rats. J Nutrit Sci Vitaminol. 2009; 55: 215-222.

PubMed: https://pubmed.ncbi.nlm.nih.gov/19602829/

7. Anju T, Sarita S. Suitability of foxtail millet (Setaria italica) and barnyard millet (Echinochloa frumentacea) for development of low glycemic index biscuits. Malyasian J Nutrit. 2010; 16: 361-368.

PubMed: https://pubmed.ncbi.nlm.nih.gov/22691989/

8. Thathola A, Srivastava S, Singh G. Effect of foxtail millet (Setaria italica) supplementation on serum glucose, serum lipids and glycosylated hemoglobin in type 2 diabetics. Diabetol Croatica. 2010; 40: 23-28.

9. Singh J, Dartois A, Kaur L. Starch digestibility in food matrix: a review. Trends Food Sci Technol. 2010; 21: 168-180.

10. Venn BJ, Mann JI. Cereal grains, legumes and diabetes. Eur J Clini Nutrit. 2010; 58: 1443-1461.

PubMed: https://pubmed.ncbi.nlm.nih.gov/15162131/

11. Annor GA, Marcone M, Bertoft E, Seetharaman K. In Vitro Starch Digestibility and Expected Glycemic Index of Kodo Millet (Paspalum scrobiculatum) as Affected by Starch-Protein-Lipid Interactions. Cereal Chem. 2013; 90: 211-217.

12. Nicoll R, Henein MY. Ginger (Zingiber officinale Roscoe): a hot remedy for cardiovascular disease? Int J Cardiol. 2009; 131:408-409. PubMed: https://pubmed.ncbi.nlm.nih.gov/18037515/

13. Ali BH, Blunden G, Tanira MO, Nemmar A. Some phytochemical, pharmacological and toxicological properties of ginger (Zingiber officinale Roscoe): A review of recent research. Food Chem Toxicol. 2008; 46: 409-420.

PubMed: https://pubmed.ncbi.nlm.nih.gov/17950516/

14. Sengev IA, Ingbian EK, Gernah DL. Sensory and storage properties of instant kunun-zaki: a non-alcoholic fermented sorghum beverage supplemented with mango mesocarp flour. Nigerian Food J. 2010; 28 : 336-346.

15. Sekwati-Monang B, Gänzle MG. Microbiological and chemical characterisation of ting, a sorghum-based gluten-free fermented cereal product from botswana. 2011; 150: 115-121

PubMed: https://pubmed.ncbi.nlm.nih.gov/21862164/

16. Kure OA, Wyasu G. Influence of Natural Fermentation, Malt Addition and Soya Fortification on the Sensory and Physicochemical Characteristics of Ibyer-Sorghum Gruel. Adv Applied Sci Res. 2013; 4: 345-349.

17. Al-Amin ZM, Thomson M, Al-Qattan KK. Anti-diabetic and hypolipidaemic properties of ginger (Zingiber officinale) in streptozotocin-induced diabetic rats. Br J Nutr. 2006; 96: 660-666. PubMed: https://pubmed. ncbi.nlm.nih.gov/17010224/

18. Shanmugam KR, Mallikarjuna K, Kesrireddy N, Sathyavelu RK. Neuroprotective effect of ginger on antioxidant enzymes in streptozotocininduced diabetic rats. Food Chem Toxicol. 2011; 49: 893-897. PubMed: https://pubmed.ncbi.nlm.nih.gov/21184796/

19. Adekunle AA. Agricultural innovation in sub Saharan Africa: experiences from multiple-stakeholder approaches. Forum for Agricultural Research in Africa, Ghana. 2012.

20. AOAC. Official methods of analysis, Association of Official Analytical Chemists. 19th ed. Washington DC chapter. 2012; 33: 4-140 .

21. Bergmeyer HU, Scheibe P, Wahlefeld AW. Optimization of methods for aspartate aminotransferase and alanine aminotransferase. Clini Chem. 1978; 24: 58-73.

PubMed: https://pubmed.ncbi.nlm.nih.gov/22409/

22. Black CD, Herring MP, Hurley DJ, O'Connor PJ. Ginger reduce Muscle Pain Caused by Eccentric Exercise. J Phytother Res. 2010; 11: 894-903. PubMed: https://pubmed.ncbi.nlm.nih.gov/20418184/

23. $\mathrm{FAO} / \mathrm{WHO}$. Human vitamin and mineral requirements $\mathrm{FAO} / \mathrm{WHO}$ expert consultation on human vitamin and mineral requirement. 2001; 1-286.

24. Kaplan A, Laverne L. Szabo. Clinical Chemistry: Interpretation and techniques. $2^{\text {nd }}$ Edition. 2003.

25. Kalui CM, Mathara JM, Kutima PM. Probiotic potential of spontaneously fermented cereal based foods: a review. African J Biotechnol. 2010; 9: 2490-2498.

26. Reitman S, Frankel S. Determination of glutamic-oxaloacetic transaminase. Am J Clini Pathol.1957; 28: 56-63. PubMed: https://pubmed.ncbi.nlm.nih.gov/13458125/

27. Smith DA, Baker BS, Gatti M. Mutationsin genes encoding essential mitotic functions in Drosophila Melanogaster. Genetics. 2011; 110: 647-670. PubMed: https://www.ncbi.nlm.nih.gov/pmc/articles/PMC1202585/

28. Shobana S, Malleshi NG. Preparation and functional properties of decorticated finger millet (Eleusine coracana). J Food Engine. 2007; 79: 529-538.

29. Taylor DJ. Effects of antibiotics and their alternatives. Br Poult Sci. 2001; 412: 67-687.

30. Zick SM, Djuric Z, Ruffin MT, Litzinger AJ, Normolle DP, et al. Pharmacokinetics of 6-gingerol, 8-gingerol, 10-gingerol, and 6-shogaol and conjugate metabolites in healthy human subjects. Cancer Epidemiol Biomarkers Prev. 2008; 17: 1930-1936. PubMed: https://pubmed.ncbi.nlm.nih.gov/18708382/ 